\title{
The Names of Green Bay, Wisconsin
}

\author{
FREDERIC G. CASSIDY
}

I

HE SIMPLEST-APPEARING NAMES are sometimes the hardest to pin down. A prime example is Green Bay, Wisconsin, which refers both to a large bay in northwestern Lake Michigan, separated from the main part of the lake by the hundred-mile-long peninsula of Door County, and to the city at the bottom of this bay at the mouth of the Fox River. The naming was a complex process, many aspects of which are in doubt. Green Bay was by no means the first name; in the preceding historical sequence both French and English were involved, with one or more Indian languages of the Algonkian, Siouan, and perhaps Iroquoian families. Though Green Bay appears simply descriptive (somebody was struck by the appearance of something green) it is by no means certain what the source of greenness was: it has been variously attributed to the water, to the trees, and even to plant growths in the water. There is also the strong possibility that so commonplace a name was transferred from some other place farther east, rather than being a fresh invention. Further, this kind of name may reflect an archetypal form residing in folk memory. With all these possibilities, it will at least be useful to review the evidence.

No doubt the Indians who resided along the Bay had names for it, but these were not adopted by the white man, and such records as we have are late and scanty. Legler gives Enitajghe ${ }^{1}$ as the Iroquois name. But the Iroquois were not of the Green Bay area and hardly ranged so far west, so if this name is authentic it must have been given relatively late, after the coming of the French, or as a result of the Iroquois wars against Algonkian tribes whom they drove west into Wisconsin. ${ }^{2}$ The Ojibwa (or Chippewa) name, at some time before 1853, was Bodjwilkwed. ${ }^{3}$ Wikwed means "bay," but bodj- has nothing to do with "green." It may possibly be related to bágwa, "it is shallow"; if so, the Ojibwa and the white men were impressed by quite different features. As a name for the bottom of the bay where the Fox River comes in and where there are many sand-

1 Henry E. Legler, Leading Events of Wisconsin History (Milwaukee: Sentinel, 1898), p. 101. This is in a chapter heading only; there is no further mention nor explanation, nor have I found it elsewhere.

2 The Indians at Green Bay in 1634 when Nicolet came were Menomini and Winnebago. As a result of the Iroquois wars, others moved in by 1654: Potawatomi, Sauk, Fox, Kickapoo, Mascouten, and temporarily some Huron, Ottawa, and Ojibwa.

${ }^{3}$ Friedrich Baraga, A Dictionary of the Otchipwe Language (Cincinnati: Hemann, 1853). 
bars, "shallow bay" would be appropriate enough. But the age of this name is uncertain; the Ojibwa were not around the Bay in any numbers before the mid-seventeenth century, and the name apparently remained unknown beyond their use.

The first whites to come to the region, the French, very early called it La Baye des Puants" - "the Bay of the Winnebagoes" - which rapidly became established and remained so throughout the period of French dominance. The story of this name harks back to the old belief in a Northwest Passage to the Orient. The American continent lay athwart the track to India which Columbus had sought, but explorers still hoped to find a way through the new land which would be shorter and safer than the way around it. Discovery of the St. Lawrence River fed this hope; Samuel de Champlain believed in it firmly enough to send several young men - among them Jean Nicolet - to live with the Indians, learn their languages, and prepare themselves to explore the west. Nicolet was chosen for the dangerous expedition, to make alliances with the Indians beyond Lake Huron and to learn what he could of the "River of the West" which supposedly flowed into the Pacific Ocean. Thus he became the first white man to reach Green Bay (1634).

The "evidence" which kept up Champlain's hopes was the report trickling back from the region of Lake Huron that farther west there lived a people whom the Algonkians called "Winnebago."' In Algonkian this was said to mean "bad-smelling water" and was given because these people were thought to have come from a distant region where such water was found. The word could alternatively be translated "salt water." Hence, westward of Lake Huron, la Mer Douce (the Freshwater Sea), the French expected to find la Mer Salée (the Saltwater Sea) on which dwelt les Gens de Mer (the Sea People) or les Peuples de l'Eau Puante (the Bad-Smelling-Water People) - the Winnebago. Though this last was repeatedly declared to be the proper and correct meaning, refer-

4 The name is spelled in varying ways but with trivial differences. Sometimes $l a$ is omitted; sometimes de is used for des. Capitalization is erratic and the diaeresis mark occasional: bä̈e. Leaving these aside, it may be worth noting that within the period from 1647 to 1727 in the Jesuit Relations and Allied Documents, ed. Reuben Gold Thwaites (Cleveland: Burrows, 1897) (hereafter $J R$ ), baye occurs 44 times against baie 12 times, while puants occurs 26 times against puans 24 times. Puan occurs once (Wisconsin Historical Collections) [Madison: State Historical Society, 1903]) (hereafter WHC) 1.26, puante once (WHC 16.298), puantz twice (WHC 59.96, 162). Thus the commonest usage was la Baye des Puants. Map spellings vary in about the same proportions.

5 This is a modern spelling, as in Winnipeg, from the same source. The common early French spelling was Ouinipigou (see further footnote 34 below). In $J R 5.279$, notes, A. F. Hunter mistakenly takes the "gents puants" to be an Algonkian tribe. The Winnebago are Siouan; their name in their own language is Hochungara (in early documents Otchagra, etc.), the fish(-totem) people (other translations have been proposed). A good account of the expectations of finding the sea of Japan and China to the west is in $J R 45.220-224$. 
ring to the place of origin, ${ }^{6}$ it was misapplied from the beginning to the Indians themselves, ${ }^{7}$ who were therefore called les Puants (the Stinkers), and this nickname became common usage.

The earliest (1648-9) full and accurate account both as to geography and the source of the names, that of the Jesuit missionary, Father Hierosme Lalement, is worth quoting at some length:

A peninsula or fairly narrow strip of land [Upper Michigan] separates this highest Lake [Lake Superior] from another third Lake, which we call le Lac des Puants [Lake Michigan], which discharges also into our freshwater sea [Lake Huron], by a mouth which is on the other side of the Peninsula about ten leagues farther west than le Sault [Sault Ste. Marie]. This third Lake stretches between west and southwest ... and is inhabited by other people with an unknown language, that is to say which is neither Algonkin nor Huron. These people are called les Puants, not because of any bad odor which may be peculiar to them, but because they are said to have come from the shores of a sea very far-removed towards the West, of which the water is salt, they are called the people of the stinking water. $^{8}$

Lalement is careful to exonerate the Indians themselves, as did others of the missionary Fathers later, ${ }^{9}$ but they did not succeed in correcting the misconception even among their own group. ${ }^{10}$ And by the common man, the fur-trader and adventurer, it was applied directly to the Winnebago and understood literally. ${ }^{11}$ This belief was extremely tenacious. As late as

6 JR 18.230, 1640, Father Paul le Jeune: "these people are called Ouinipigou because they come from the shores of a sea about which we know nothing, and therefore they ought not to be called the nation of Stinkers, but the nation of the sea (la nation de la mer)." This and later translations are mine.

$7 J R 23.276$, 1642-3, Father Barthelemy Vimont.

8 JR 33.148, 150. The name Lac des Puans was applied first to Lake Michigan, as here. But that soon became Lac des Illinois, so Lac des Puans was then restricted to the Bay (see Louise P. Kellogg, Early Narratives of the Northwest 1634-1699 [New York: Scribner, 1917]). On the map between pages 228-229, made "to illustrate Marquette's discoveries" of 1672-3, Lake Michigan is Lac de Michigami ou Illinois. A short time later the bay became la Baye des Puants. Still later, when the Winnebago Indians left Green Bay and settled near present Lake Winnebago, Lac des Puans was transferred once more to this lake. When the English came they converted the name to Lake Puan or Puans Lake - see James Gorrell's Journal (1761) in WHC 1.26.

9 J R 41.78, 1653-4, Father François de Mercier; 54.196, 1669-70, Father Claude Allouez.

$10 J R$ 15.154, April 1639, Father François du Peron.

11 Abbreviated nicknames were commonly used for the Indians: the Folles-avoines (Menomini) became les Folles (crazy-ones); the Poutaouatamis (Potawatomi) became les Poux (lice), etc. One reason given for this practice was that if the Indians heard their right tribal names being used in French context, they suspected they were being spoken of for some secret purpose. 
1721 one still finds Father Charlevoix presenting it in a new guise. By this time the Winnebago had left the Bay and were living along present Lake Winnebago. He writes:

They (the Otchagras, commonly called the Puants) settled upon the shores of a sort of Lake; and I know not whether it is not for that reason, that, living on Fish, of which the Lake furnished them great abundance, one gave them the name of Stinkers, because all along the shore where their Cabins were built, one saw nothing but rotten Fish, with which the air was infected. It appears at least that that is the origin of this name, which the other Indians had given them before us, and which was transferred to the Bay, from which they have never strayed far. ${ }^{12}$

And as late as 1857 we find the story still alive in Augustin Grignon's recollections:

Their name of Winnebagoes seems to have been given them by the Menomonies - Win-ne-pa-go, or Filthy, expressive of their filthy habits, and which characteristic led the early French to denominate them les Puants, the Stinkards. ${ }^{13}$

A second way of misunderstanding Puants was to make it refer in one way or another to the Bay and its surroundings rather than to the Indians. From as early as 1659 Father Lalement writes of

le lac des Oüinipigouek [Lake of the Winnebagoes], which is properly no more than a large bay of Lake Huron; others call it le lac des puans, not that it is salty like the water of the Sea, which the Indians call Oüinipeg, that is to say stinking water: but because it is surrounded by sulphurous lands, from which issue certain springs which bring into this lake foulness contracted by their waters in their places of origin. ${ }^{14}$

Ten years later, Father Claude Allouez explains the smell as coming not from sulfur but from stagnancy: "The water of this Bay and of the Rivers is like that which stagnates in ditches." 15 And the following year he states that the Bay

bears this name, which is the same as the Indians [sauvages] give to those who live close to the sea, perhaps because the odor of the

12 WHC 16.412. This quotation is translated from Journal d'un Voyage fait par ordre du roi dans l'Amerique Septentrionale ... par le P. de Charlevoix (Paris: Giffard, 1744) V, p. 431 .

13 WHC 3.286.

$14 J R$ 45.218: "il est enuironné de terres ensouffrées, d'ou sortent quelques sources qui portent dans ce lac la malignité que leurs eaux ont contractées...."

$15 J R$ 54.206: "l'eau de cette ance \& des rivieres, y est pareille à celle qui croupit dans les fossez." 
swamps with which this Bay is surrounded has something of that of the sea; and besides it would be difficult to find on the Ocean more impetuous windstorms than those which are experienced in this place, with extremely violent and almost continual thunder. ${ }^{16}$

Pierre Radisson, the French trader who came through the Green Bay region about 1656, writing later in an English which was less than accurate, refers to the Bay as "the great lake of the Stinkings." 17 Again, in 1673-7, Father Claude Dablon, describing Marquette's first voyage, generally agrees with Allouez:

This bay bears a name which has not so ill a meaning in the language of the savages, because they call it the salt bay [la bä̈e sallee ], rather than the bay of the stinkers, although among them it may be almost the same; as it is also the name they give to the sea....18

Accordingly, he says, he has sought for evidence of salt springs in the region, but without success. He continues:

Thus we judge that it was given this name because of the quantity of ooze and mud that one finds there, from which constantly arise evil vapors which cause the greatest and most continual thundering that I have ever heard. ${ }^{19}$

Yet another theory is that of Father Thierry Beschefer (1681-3), who writes of 'the Bay which is called 'des puans' for not having properly understood the Indian word which means waters smelling of rushes [le jonc]."'20

Finally, the too obvious explanation, merely asserted, quite late (1846), without historical or other justification, is that of Increase Lapham: "Green Bay - Derives its name from a fancied deeper green color of its waters than usual." ${ }^{21}$ One has a right to assume that Lapham got this by hearsay or simple inference.

That there were swamps, shallows with stagnant water, mud, and reeds or rushes in the Bay and near the settlements cannot be doubted, though

\footnotetext{
$16 J R 55.182$.

17 "Radisson's Account of his Third Journey, 1658-1660 (1654-56?)" in Kellogg, op. cit., p. 46. This may be no more than a bad translation of Le grand lac des Puants.

${ }^{18} J R$ 59.96. "La baye Salée" represents translation from the Indian; it probably had little or no currency as a name.

19 Ibid., pp. 96, 98.

${ }^{20} J R$ 62.202. Baraga's Ojibwa words for reeds or rushes (anákanashk, apakwéshkwai) cannot be related to Winnebago.

${ }^{21}$ Henry E. Legler, "Origin and Meaning of Wisconsin Place-Names," in Trans. Wis. Academy of Sciences, Arts, and Letters 14, part 1 (1903), p. 35.
} 
the Great Lakes waters in general were anything but foul..$^{22}$ These explanations of strong odors, perhaps somewhat exaggerated, must be based either on some unusual or temporary condition, or else they are ex post facto attempts, by people who did not know its true origin, to explain Puants without insulting reference to the Indians. The latter appears to me the more likely.

La Baye des Puants, however, seems to have been uncomfortably long for day-to-day use: by 1672 it was already being abbreviated to La Baye. ${ }^{23}$ This shorter form applied especially to the settlement and to Fort La Baye, built in 1717. ${ }^{24}$ And when the English and Americans came, they anglicized it in brief forms: La Bay, the Bay, Puans Bay. ${ }^{25}$ This general desire for a short name may well have been one reason why Green Bay, once introduced, was rapidly adopted.

Early alternatives to La Baye des Puants were attempted, but none achieved any real currency. In 1640, before the distinction was clearly made between its status as a lake or a bay, one finds it called Le Lac des Gens de Mer, the Lake of the People of the Sea. ${ }^{26}$ In 1669, Nicolas Perrot first came through the region to what he called la baye des Renards et Miamis, the Bay of the Fox and Miami Indians. ${ }^{27}$ If this was intended as a name, it was not taken up by others, and when he returned 20 years later, Perrot accepted the current name - Baye des Puans.

The Potawatomi Indians were also used to identify the Bay since they lived, at the time of early explorations, chiefly on the islands separating it from the Baye des Noquets (now Bay de Noc). Thus in 1670 we find

${ }^{22}$ WHC 7.266-7 (1876), Albert G. Ellis' Recollections: "The head of Green Bay near the mouth of the Fox River, is bordered with extensive marshes of reed grass and rushes, giving the water a green tinge, and it appears stagnant; and, at first view would be supposed as a fitting place for generating malaria and disease. All strangers have concluded at once it must be a terribly sickly region, while the truth is, Green Bay is proverbially one of the healthiest localities on the globe." This gives equal credit to all favorable explanations.

${ }^{23} J R 57.304$ (1672-3); $69.192(1710-56)$; etc. English writers at first adopted the French form ( $W H C$ 18.237, 1761).

${ }^{24}$ Other names for this fort were Fort St. Francois and Fort St. Philippe. The English rebuilt it as Fort Edward Augustus (1761) and the Americans as Fort Howard (1816). Louise P. Kellogg, The French Régime in Wisconsin (Madison: State Hist. Soc., 1925), p. 292 , note 6.

${ }_{25} L a$ Bay (WHC 1.25; 18.245, 264, 265, 266 - 1764), or in a letter, $L a B a$ (WHC 18.446 - 1796); the Bay (WHC 18.263, 264, 266-1764). John Pattin ( ?) has Lake de Puans, evidently for the Bay, and River d' Puans for the Fox River (WHC 18.146 - 1754).

${ }_{26} \mathrm{Le}$ Lac des Gens de Mer, a "correct" rendering of Ouinipigou (Winnebago); also rendered as $l$ ' $A c$ [i. e., lac] de la Nation Maritime and lac des peuples maritimes, $J R$ 46.76, 1661, Father Sebastien Cramoisy.

27 Jules Tailhan, ed. Mémoire de Nicolas Perrot (Paris: Franck, 1864), pp. 127 and 290, note 4. These two tribes were then living at or near the Bay. 
the name Baie des Poutéotamiques. ${ }^{28}$ And much later the Menomini were identified with it, for, according to Jonathan Carver, who came there in 1766, "it is termed by the inhabitants of its coast, the Menominie Bay; but why the French have denominated it the Puant or Stinking Bay I know not." 29

In 1672 one finds la baie de saint Xavier, which refers to the mission established by Father Allouez close to the Bay. ${ }^{30}$ In the same year appears la grande baye des Puans, ${ }^{31}$ in which grande may be merely descriptive, though La Grande Baie appears again in 1721.32 Much later (1827) governor James Doty used Grand Bay for the bay itself while on the same page referring to the city as Green Bay ${ }^{33}$ Can it be that Grand $B a y$, an obvious anglicizing of la Grande Baye, was kept up in local use until Doty's time, and that he knew this tradition? Or did he derive the name from historical reading? No further record has been found. At least, this attempt to have different names for the bay and the city is probably Doty's. ${ }^{34}$ But it won no acceptance.

The translation of Winnebago as "ill-smelling or salt water" has been accepted hitherto without any objection. Yet this translation is suspect. Ojibwa wini- means dirty, filthy. By extension it might imply bad odor, though "it stinks" is manjimagwad, a quite unrelated form. Words referring to "salt," jiwitágan and "salt water," jiwitaganabo are similarly unrelated. Thus "ill-smelling" or "smelling or tasting of salt" are inadequate renderings of the first part of Winnebago. ${ }^{35}$

Further, the spelling Winnebago (and its pronunciation) is misleading, Winnipeg somewhat less so; the original French form, Ouinipigou, was much the closest to the Indian source. We cannot be sure which of the Algonkian peoples gave this name in the first place, though probability favors the Menomini since they and the Winnebago were the earliest tribes dwelling on the Bay in historic times. In the Menomini language,

${ }^{28}$ M. de Galinée, Carte du Pays que M. M. Dollier de Casson et de Galinée ... ont parcouru (State Hist. Soc. of Wisconsin, 1670).

${ }_{29}$ Travels through the Interior Parts of North America (London: J. Walter, 1778), p. 27. His second map (between pages xvi and 17) gives Green Bay. The Menomini were still settled on the Bay; the Winnebago had moved inland; and Carver does not seem to have realized that Puant referred to the latter.

${ }^{30} J R$ 57.302, Father Louis André. The Mission des Pères gave its name to present De Pere.

$31 J R$ 57.204, Father Jean de Lamberville. Also in 1697: R. P. Louis Hennepin, Nouvelle Decouverte d'un Tres Grand Pays ... (Utrecht: Brodelet, 1697), p. 52.

${ }^{32}$ Father Charlevoix - see note 12 above.

${ }^{33} W H C$ 13.245.

${ }^{34}$ Doty was idiosyncratic about place-names. He tried to have the spelling "Wiskonsin" (1827) and later "Wiskonsan" (1842) adopted for the name of the Territory, but the Legislature rejected this and made "Wisconsin" official (1848). WHC 11.464, 478; 15.378.

35 Baraga, op. cit. 
closely related to Ojibwa, the name would mean "dwellers by dirty water" 36 - and this dirty water may well have been that of Green Bay itself, rather than some other, more remote place of origin. Since the Menomini did not go east, their name for the Winnebago - a non-Algonkian people - must have been taken eastward into Canada by some other Algonkian people, most likely the Ojibwa and Ottawa, and so to the French. The farther east this story was taken, of the dirty-water people who spoke a strange tongue, the more remote these people became. And the dirty water turned into stinking or stagnant water or even salt water, this last probably a product of the explorers' wishful thinking, their hope for the Northwest Passage, and of the Indians' reluctance to disappoint them.

So much for the early names. When and how did the great shift come about from La Baye des Puants to La Baye Verte or Green Bay? French settlement was greatly delayed by wars with the Indians which continued till 1740. Thus, leaving aside the Mission of St. Francis Xavier (which the Indians burned in 1687), there was no lasting settlement till about 1750. Then by 1760 the British occupied the area and kept control of it until after the war of 1812 - in fact, till 1816. The mid-eighteenth century and just after is therefore the important time for the coming of the new name. But which was the original language, French or English? In which direction did the translation go ? I have found no previous attempt to answer this question. Once the name was introduced and had gained some degree of acceptance, no doubt the English-speakers would say Green Bay and the French-speakers would say la Baye Verte. But one side or the other must have begun it. What are the probabilities?

The two earliest English records appear to be those of Jonathan Carver and Peter Pond. Though Carver's book was not published till 1778, ${ }^{37}$ his present-tense account suggests that he wrote or took notes as he went along, and it is probably safe to take it as contemporary with his visit in 1766 :

We accordingly set out together, and on the 18th arrived at Fort La Bay. This Fort is situated on the southern extremity of a Bay in Lake Michigan, termed by the French the Bay of Puants; but which since the English have gained possession of all the settlements on this part of the Continent, is called by them the Green Bay. The

${ }^{36}$ The Rev. E. P. Wheeler, Geographic Names of Chippewa Origin (State Hist. Soc. of Wis. MS), quoted in Henry E. Legler (see note 20) 35, gives: Ween-nih-beeg-gog, dwellers by dirty water. Chrysostom Verwyst, O. S. F., "Geographical Names..." in WHC 12.398 gives Winnibigoug (dirty-water people).

37 Carver's authorship has been strongly disputed and defended - see Louise P. Kellogg, The British Régime in Wisconsin and the Northwest (Madison: State Hist. Soc., 1935), pp. 62-4. 
reason of its being thus denominated, is from its appearance; for on leaving Michillimackinac in the spring season, though the trees there have not even put forth their buds, yet you find the country around La Bay, notwithstanding the passage has not exceeded fourteen days, covered with the finest verdure, and vegetation as forward as it could be were it summer. ${ }^{38}$

If Carver is right, the English introduced their own name Green Bay while the French clung to the traditional one. If so, Green Bay would naturally displace the longer and now foreign Baye des Puants, since the English language had become dominant and was to remain so.

Peter Pond, a Yankee merchant traveling through in 1773, uses the name twice: "On my way to Grean Bay at the Mouth of fox river," and "We Descended the fox River to the Botam of Greane Bay so cald....",39 His phrase "so called" implies that the name by this time was in common oral usage, though it would have been slower to get on to maps. From these two accounts we get the distinct impression that, once introduced, the new name was quickly accepted.

On the other hand, there is a distinct possibility that the French had already introduced la Baye Verte before Carver arrived. ${ }^{40}$ Carver's explanation of its meaning - a very plausible one - could apply equally well to la Baye Verte: the French must often have observed the sudden greening of the trees as they paddled or sailed down from Mackinac many years before the English came upon the scene. One such voyager, Father Charlevoix, traveling in 1721 to la Grande Baye from Michillimackinac, and passing down the northwest side, stopped on an island near the mouth of the Menominee River. Continuing the next day, he writes

A little below the Island of which I just spoke, the country suddenly changes aspect, and from being rather wild, which it is up to there, it becomes the most attractive in the world. It even has something more pleasing than the Détroit, but although it is covered everywhere with very beautiful trees, it is much sandier and less fertile. ${ }^{41}$

So Charlevoix was one of those who were early struck with the verdancy of La Baye. If, later, the English were looking for a French name to adopt, la Baye Verte, brief and simple to translate, would surely attract them more than la Baye des Puants.

38 Op. cit., p. 21.

39 "The Journal of Peter Pond," $W H C$ 18, respectively 329, 344.

40 The earliest actual record $I$ have found is 1815 in the heading of a letter from Pierre Grignon to his brother Louis, dated 17 June: La Bay verte (WHC 19.375). The Grignons were one of the French-speaking families which remained after the English came. Baye Verte is used as late as 1868 in the marriage certificate of Dominique Brunette and Domithile Grignon - Brown County Mortgages 14.441, Register of Deeds Office, Green Bay.

41 From Journal d'un Voyage. ., 431. See note 12. 
There is another reason in favor of French priority. Place-names in new settlements very frequently repeat those of older settlements. As settlers move west they replant the eastern names - and before the English came to Wisconsin there were already a Bay Verte in Newfoundland ${ }^{42}$ and another in Nova Scotia. ${ }^{43}$ The Newfoundland example (now Bay de Verde) appears first on Blathwayt's map of ca. 1630-40 as Bay Verde. ${ }^{44}$ The French form probably preceded the English, though John Guy, Governor of the first English colony in Newfoundland, was the first to record it: Greene Bay, 1612.45 The Nova Scotia Baye Verte appears first on a map of $1699,{ }^{46}$ though it, too, had probably been named earlier. In any case, these two Baye Vertes must have been commonly known to navigators of the St. Lawrence River and Gulf, and, as we have seen, the English were quick to render them into their own language. A later example is found in French Policy Defeated (1755):

This Gulph [of St. Lawrence] is six Leagues long, and only one League broad; the navigation of it is very gcod, as appears from the Journal of Captain Gayton, who passed it in 1746, on a cruise to Green Bay.... Green Bay, or Bay Verte, lies 14 Leagues further [beyond the Gut of Canso], and is shallow Water.... It is proper here to take Notice, that on the side of Chignecto Bay, the Tide flows eleven Fathoms: But on the Gulph of St. Lawrence or Green Bay Side, the swell is not above four or five Feet. ${ }^{47}$

Though this makes a case for the possibility that the French first brought Baye Verte to Wisconsin and the English changed it to Green $B a y$, conclusive evidence has not been found. There seems no good reason why, with La Baye des Puants and La Baye so long established, the French should have occasion to introduce a new name. Meantime, there is Carver's perfectly clear distinction between what the French and the English call the bay, which implies that the new name was English. ${ }^{48}$ This does not weaken the possibility of transference from one of the easterly places, Baye Verte or Green Bay, especially for so commonplace a name. Yet the on-the-spot character of Carver's explanation makes it very compelling. Probability would seem in the end to weigh in favor of a new name (perhaps trailing an echo from the Maritime Provinces) being introduced by the English for the reason Carver gave, which came out of direct observation.

${ }^{42}$ On the NW of Conception Bay, approximately $46^{\circ} \mathrm{N}, 64^{\circ} \mathrm{W}$.

${ }^{43}$ On the border of New Brunswick, approximately $46^{\circ} \mathrm{N}, 53^{\circ} \mathrm{W}$.

${ }^{44}$ In E. R. Seary, Place Names of the Avalon Peninsula of the Island of Newfoundland (Toronto: Univ. Press, 1971), pp. 176, 313. 45 Ibid., pp. 58, 371.

${ }^{46}$ Franquelin, Partie de l'Amerique Septentrionalle, State. Hist. Soc. of Wis.

47 Anon, (London: M. Cooper), p. 35.

48 Tailhan, op. cit., alphabetic index, III, seems to accept this: "Baie (la Grande) appellée aussi par les Anglais Baie verte (Green Bay)." 
To summarize: La Baye des Puants was the generally accepted French name, used from the early seventeenth into the late eighteenth century. Based on a mistaken translation, then misapplied to the Indians instead of to their place of origin, it caused confusion which led to several attempts to rationalize it. Perhaps these uncertainties were one factor in its commonly being abbreviated to la Baye. Shortly after 1660, with the end of the French régime, a new name was introduced by the English: Green Bay, which gained rapid acceptance and which, after some time, the French inhabitants of la Baye converted into (la) Baie Verte, but this never gained more than local currency within their group. Green Bay, while in form no new invention, was very probably due to the phenomenon noted by Charlevoix and described by Carver: the greenness of the foliage in contrast to that of Mackinac and the wild northwest coast of the Bay. These "conclusions," while not conclusive, bring us closer to the probable facts. We end with a list of the names which Green Bay has borne at various times, with some indication of the degree of currency gained, or not gained, by each.

INDIAN NAMES:

Enitajghe (Iroquois) - date and currency uncertain

Bodjwikwed (Ojibwa) - before 1853; currency uncertain

FRENCH NAMES:

Le Lac des Gens de Mer - 1640, briefly

Le Lac des Oüinipigouek - 1659, one record only

Le Lac de la Nation Maritime - 1659-60, one record

Le Lac des Peuples Maritimes - 1659-60, one record

Le Lac des Puants - map about 1675; brief early use if any

La Baye des Puants - about 1634 till late eighteenth century

La Baye des Renards et Miamis - 1669, one record only

La Baye des Poutétamiques - 1670, briefly

La Baie de Saint Xavier - 1672, one record only

La Grande Baye des Puants - 1672-3, little currency

La Baye - 1672-3 till late nineteenth century

La Baie Salée - 1673-7, translation, probably no currency

La Grande Baie - 1721, occasionally

La Baye Verte - before 1815 till 1868 or later

ENGLISH NAMES:

La Bay - 1761, during transition period

The Bay - 1764 to present

Menominie Bay - 1766, probably little currency

Puans Bay - 1766, during transition period

Stinking Bay - 1766; translation, probably no currency

Green Bay - before 1766 to present

Grand Bay - 1827, doubtful currency

Packerland - unofficial nickname since 1950's.

The University of Wisconsin 